\title{
Sagsbehandling i en digital virkelighed: Digitalisering, standardisering og indivi- duelle hensyn
}

\author{
Matilde Høybye-Mortensen \\ Forsker, Ph.d., Det Nationale Analyse- og Forskningsinstitut for Kommuner og Regioner
}

Digitalisering indenfor kommunal velfærd har medført standardiserede sagsbehandlingssystemer som for eksempel Fælles Sprog, der bruges på ældreområdet. Denne artikel undersøger, hvordan kommunale sagsbehandlere håndterer at anvende et standardiseret system og samtidigt tage individuelle hensyn til den ældre som loven kræver.

\section{Indledning: Den digitale vej til velfærd}

Brug af teknologi til forvaltning af socialområdet er et af fokuspunkterne i digitaliseringsstrategien: "Den digitale vej tilfremtidens velfard 2011-2015”. I strategien, der er udviklet af Løkke Rasmussen regeringen og siden tiltrådt af Thorning-Schmidt regeringen, står "Effektive it-redskaber kvalificerer og effektiviserer sagsbehandlingen pà det sociale område. Der er sarligt fokus $p a ̊$, at redskaberne gør en forskel $i$ sagsbehandlernes hverdag" (Regeringen 2011: 26). På socialområdet er der de senere år blevet udarbejdet sagsbehandlingssystemer på de store sektorområder indenfor velfærd. Det gælder områder som ældre, udsatte børn og unge og senest handicappede og udsatte voksne. KL og
Social- og Integrationsministeriet har været primus motor på udviklingen. Digitale sagsbehandlingssystemer som DUBU (Digitalisering Udsatte Børn og Unge) og DHUV (Digitalisering Handicap og Udsatte Voksne) indgår i den fællesoffentlige digitaliseringsstrategi, hvor Fælles Sprog III indgår i den fælleskommunale digitaliseringsstrategi.

Skandaler som AMANDA, den digitale tinglysning og senest politiets nye sagsbehandlingssystem POLSAG kan synes at gøre de høje forhåbninger til digitalisering til skamme eller i bedste fald bruges til at afvise de høje forventninger som naive (se fx Bjørnholdt 2011 for beskrivelse af POLSAG). En mere optimistisk tilgang er, at fejlslagne digitaliseringsprojekter blot er eksempler på opstartsvanskeligheder, da de offentlige organisationer agerer i ukendt farvand og i høj grad forsøger sig frem, hvorfor der på sigt ligger et stort og forandrende potentiale derude et sted (Bovaird 2005, OECD). Uanset om forventningerne er naive eller realistiske, så er digitalisering af arbejdsprocesser og indførsel af nye teknologier værktøjer, der anvendes i styringen af den offentlige sektor. Digitalisering præsenteres som løsningen på nogle styringsmæssige udfordringer og som et effektiviserings-

Tabel 1. Eksempler på digitale sagsbehandlingssystemer på socialområdet

\begin{tabular}{|l|l|l|}
\hline Sagsbehandlings-system & Sektor & Afsender og udvikler \\
\hline Fælles Sprog (1998 - nu er vi nået til Fælles Sprog III) & ÆEldreområdet - visitation til hjemmehiælp & Socialministeriet og KL \\
\hline $\begin{array}{l}\text { Digitalisering Udsatte Børn og Unge (DUBU) } \\
\text { (i drift fra 2012) }\end{array}$ & $\begin{array}{l}\text { Børn og familieområdet - sager om familiestøtte, } \\
\text { jjernelser af børn etc. }\end{array}$ & Socialministeriet og KL \\
\hline $\begin{array}{l}\text { Digitalisering Handicap- og Udsatte Voksneområdet } \\
\text { (DHUV) (2012) }\end{array}$ & $\begin{array}{l}\text { Handicap og udsatte voksne - fx sager om boligtillbud } \\
\text { eller boligstøtte }\end{array}$ & Social - og Integrationsministeriet og KL \\
\hline
\end{tabular}


værktøj, seneste eksempel er Thorning-Schmidt regeringens 2020-plan, hvor øget digitalisering er anført som redskab til modernisering af den offentlige sektor (Regeringen 2012).

Der er tre digitaliseringssfærer i den offentlige sektor: - borger/myndighed, - internt administrative arbejdsgange (som fx sagsbehandlingssystemer) - og tværgående infrastruktur.

I implementeringen af politik er der tre styringsarenaer: 1 styring mellem politikere og forvaltning, 2. styring internt i forvaltningen $\mathrm{ml}$. forvaltningsenheder og 3 . styring fra forvaltning til samfund (Lundquist 1992). På baggrund af den distinktion kan udvikling og implementering af digitale sagsbehandlingssystemer karakteriseres som intern styring i forvaltningen. Styring af forvaltningen kaldes også 'regulation inside government'(Hood, Scott et al. 1999) og 'internal policies' (Vedung 2005).

De digitale sagsbehandlingssystemer skal anvendes af kommunale sagsbehandlere med myndighedsbeføjelser. Disse sagsbehandlere står hver dag overfor at skulle træffe afgørelser om borgeres ret til ydelser og services. Afgørelserne er underlagt lovgivning fx Lov om social service eller Lov om aktiv beskaftigelsespolitik. Der er dog ikke fastsat en aldersgrænse for, hvornår man kan få hjemmehjælp, eller et fast antal måneder man kan gå ledig, før kontanthjælpen stoppes. I Servicelovens $₫ 88$ står, at kommunalbestyrelsen skal træffe afgørelser om tildeling af hjemmehjælp på baggrund af "en konkret individuel vurdering af behovet for hjalp til de opgaver, som modtageren ikke selv kan udfore" (LBK nr. 904 af 18/08/2011).

Det betyder, at afgørelserne er skønsbaserede, og at den medarbejder, der behandler sagen, skal udøve skøn. Samtidigt er afgørelserne om tildeling af ydelser et oplagt sted at forsøge at styre, da de ydelser, der træffes afgørelser om, er udgiftskrævende. Rundt om i alle landets kommuner sidder massevis af sagsbehandlere og træffer afgørelser hver dag. Mange af de beslutninger kan ikke kontrolleres direkte ( $\mathrm{fx}$ af en leder), og der må ikke laves faste detaljerede regler i kommunerne for hvordan lovgivningen skal tolkes, da lovfæstet skøn ikke må sættes under regel. Det er også en praktisk umulighed at lave regler for alle tænkelige problemsituationer en borger måtte kunne befinde sig i.
Sagsbehandleres beslutningstagning skal derfor påvirkes indirekte, hvilket kan gøres gennem tre mekanismer. Den første er informationsafgrænsning i form af skemaer, der sætter rammer for, hvilke oplysninger om borgeren, der skal indgå i afgørelsen. Den anden er begrænsede valgmuligheder ved at lave kategorier til vurdering af borgere eller begrænse antallet af ydelser. Den tredje går ud på at etablere kontrolstrukturer, hvorigennem dokumentationen af afgørelserne kontrolleres via krav om digitale indberetninger eller mulighed for monitorering af sagsbehandling via udtræk af lister (Høybye-Mortensen 2011). Digitale sagsbehandlingssystemer kan indeholde alle tre mekanismer.

Standardisering er et vilkår for digitalisering af sagsbehandling. En stor del af arbejdet med at udvikle og implementere digitale sagsbehandlingssystemer til socialområdet består derfor $\mathrm{i}$ at udvikle modeller for et standardiseret sagsforløb og nogle faste kategorier. Det kan $\mathrm{fx}$ være en standard for en socialfaglig metode til at vurdere borgerens behov eller standardisering af andre arbejdsgange, som $\mathrm{fx}_{\mathrm{x}}$ dokumentation af afgørelser. Digitale sagsbehandlingssystemer på socialområdet skal altså både være bygget over nogle standarder og muliggøre skønsbaserede vurderinger og afgørelser. Der findes altså på den ene side, det standardiserede system og fokus på systematik og overblik og på den anden side det konkrete tilfælde, en borger, der på socialområdet kan have komplicerede problemstillinger, og som skal være genstand for en konkret individuel vurdering.

Det debatteres forsat, hvordan digitale standardiserede sagsbehandlingssystemer påvirker frontlinjens arbejdsopgaver. Mange har diskuteret hvorvidt det har en særskilt betydning, når styringsinstrumenter er digitale. Synspunkterne spænder over dikotomien 'ja, computeren betyder noget særligt' til 'nej, regler er regler ligegyldig indpakning'. Digitalisering af sagsbehandlingssystemer på socialområdet har givet visse forskere anledning til at ændre det paradigmatiske begreb 'street-level bureaucracy' til 'screen-level bureaucracy' eller 'system-level bureaucracies' (Bovens and Zouridis 2002; Marston 2006).

I disse udtryk ligger en antagelse om, at udformningen af det digitale sagsbehandlingssystem får stor indflydelse på sagsbehandleres afgørelser, da systemerne afgør

Tabel 2. Sfærer for digitalisering i den offentlige sektor

\begin{tabular}{|c|c|c|}
\hline Borger - myndighedskommunikation & Internt offentligt & Tværgående \\
\hline $\begin{array}{l}\text { At flytte sagsbehandlingsaktiviteter, så borge- } \\
\text { ren selv udfører processerne. } \\
\text { Selvbetjening på nettet i forhold til ansøgnin- } \\
\text { ger om ydelser, bestilling af tid m.m. } \\
\text { Formål: at flytte arbejdsbyrden til borgeren. }\end{array}$ & $\begin{array}{l}\text { Digitalisering af administrative processer, digitale } \\
\text { forbindelser mellem forskellige niveauer fx mellem } \\
\text { kommunens frontlinjemedarbejder og ledelse. } \\
\text { Formål: Transcendere interne organisatoriske barrierer, } \\
\text { gøre arbejdsgange lettere, muliggøre dataudtræk. }\end{array}$ & $\begin{array}{l}\text { Ønske om dataoverførsel mellem offentlige myndighe- } \\
\text { der, så borgeren kun skal indberette et sted/en gang. } \\
\text { Rammearkitektur. } \\
\text { Formål: Transcendere skel mellem organisationer og } \\
\text { genbruge data. }\end{array}$ \\
\hline
\end{tabular}

Kilde: Workshop "Indsatsområder for det digitale samfund", Digitaliser Danmark, konference, Århus d.20. marts 2012. 
hvilken information, der er plads til, mulige kategorier og i visse tilfælde udøver en afvejelse af klientforhold, der er skjult for både sagsbehandler og klienter. Det er altså en antagelse om, at digitale systemer bliver politikudmønterne i stedet for frontlinjen.

I denne artikel undersøges derfor først, hvordan sagsbehandleres arbejde udfolder sig $i$ et standardiseret digitalt system og dernæst, hvordan sagsbehandlere håndterer de modsatrettede krav om individuelle hensyn og vurderinger på den ene side og på den anden side et standardiseret system, hvor ensartethed er målsætningen.

\section{Digitalisering: hvad og hvordan?}

Men hvad dækker begrebet "digitalisering" over? Den tekniske definition er noget med nuller og ét-taller og refererer som sådan til en måde at lagre information på. I Den Danske Ordbog er digitalisering defineret således: "Digitalisering: udbredelse af elektroniske medier og computerbaserede forretningsgange"(DSL 2012), hvilket er en meget bred definition. En dansk gennemsnitskommune vil til forvaltningen af velfærdsområder benytte sig af mange forskellige digitale systemer. På et sektorområde som ældre- og handicapområdet vil der kunne være 4-5 systemer i spil. For det første et fagsystem, hvor sagsbehandlere, der visiterer til ydelser skriver vurderinger af borgerens behov. For det andet et journalsystem, hvor cpr.nr. og bevilligede ydelser på $\$$-niveau tastes. Derudover findes typisk et afregningssystem, hvor oplysninger om hvad der betales for hvilke ydelser og til hvem er registreret. Udførersiden, altså dem der leverer velfærdsydelserne, bruger måske et andet system til at beskrive borgeren, handleplaner og delmål. Derudover kan der findes systemer, hvor forhold der skal indberettes til en anden instans registreres. Det kan være forhold som magtanvendelse, eller 'særligt dyre enkeltsager', som der er statslig refusion på.

Så hvis 'digitalisering' dækker over brug af digitale teknologier, så er de kommunale forvaltninger allerede digitale. Når vendingen bruges i forbindelse med fremtidens velfærd, synes der dog at ligge betydeligt flere ting i det. Fænomener lige fra selvbetjening på internettet til velfærdsteknologier som robotstøvsugere og spiserobotter diskuteres under overskriften digitalisering.

Teoretisk er der en del uklarhed omkring begrebet digitalisering. For det første er der megen varians i sprogbrugen, dels anvendes begreber som 'IT', 'teknologi', 'digitalisering', 'elektroniske systemer' og på engelsk bruges begreberne 'computerization', 'digitization', 'technology' og 'ICT' (Information and Communication Technology) med flere. Det er derfor vanskeligt at afgøre, hvorvidt forskellige videnskabelige artikler og bøger behandler det samme emne, og om det er på samme analytiske niveau. Der er ligeledes forskel på, om det er en proces, hvor noget bliver gjort digitalt, eller der er tale om implementering og brug af digitale teknologier, der er i fokus. Hvis man gerne vil sige noget om digitalisering i den offentlige sektor, er det derfor relevant med tydelighed og konkretisering af hvad og hvordan der digitaliseres.

Denne artikel behandler digitalisering i den internt offentlige sfære. I artiklen undersøges det digitale sagsbehandlingssystem Falles Sprog, der anvendes af sagsbehandlere på ældreområdet. Ved at tegne et billede af hvad "digital forvaltning" kan være indenfor det kommunale velfærdsområde graves der i artiklen et spadestik dybere i forhold til en bestemt måde at digitalisere på - digitale sagsbehandlingssystemer - i en bestem kontekst - kommunal forvaltning på velfardsområdet.

\section{Fælles sprog: Et standardiseret digitalt sagsbehandlingssystem}

Med udgangspunkt i et studie af sagsbehandleres anvendelse af digitale sagsbehandlingssystemer diskuteres samspillet mellem individuelle skønsmæssige vurderinger og brugen af digitale standardiserede sagsbehandlingssystemer i den kommunale velfærdssektor. Termen sagsbehandler er brugt som betegnelse for medarbejdere, der træffer myndighedsbeslutninger på socialområdet. Sagsbehandlere på ældreområdet kaldes visitatorer (idet de visiterer til hjemmehjælp) og betegnelsen visitator vil blive brugt, når det handler specifikt om sagsbehandlere på ældreområdet.

Først undersøges hvordan visitatorers arbejde udfolder sig i Falles Sprog. Dernæst undersøges, hvordan visitatorerne håndterer de modsatrettede krav mellem på den ene side individuelle hensyn og vurderinger og på den anden side et standardiseret system, hvor ensartethed er målsætningen.

Artiklen bygger på et studie af tre forskellige sagsbehandlingssystemer (ICS, Fælles sprog og Dialogguiden) og deres påvirkning af kommunale sagsbehandleres beslutningstagning og skønsmæssige råderum. Data bestod $i$ alt af 30 gruppeinterview med sagsbehandlere, der anvendte systemerne, samt officielle dokumenter der beskrev systemerne (se Høybye-Mortensen 2011). Denne artikel behandler et delelement, nemlig standardiserede kategorier og der indgår udelukkende fund fra studiet af Fælles Sprog. Interviewene blev systematisk gennemgået i forhold til, i hvilke situationer og hvordan Fælles Sprog påvirker visitatorernes skønsmæssige råderum. Der er foretaget interview med 18 visitatorer fra 10 forskellige kommuner. Talesprog er meget langt fra skriftsprog, derfor er citaterne i denne artikel redigeret af hensyn til læsevenlighed og forståelighed.

\section{Udviklingsforløb for Falles Sprog}

I 1976 var der ca. 100.000 modtagere af hjemmehjælp (Hansen and Vedung 2005: 277). I 2008 var antallet af personer der fik varig hjemmehjælp steget til 183.270 
Tabel 3. Beskrivelse af Fælles Sprog

\begin{tabular}{|l|l|l|}
\hline Anvendelsesområde & Standardiseret vurdering & Standardiserede ydelser \\
\hline Bruges af kommunale visitatorer, der vur- & Funktionsvurderingsvurderingsskemaet indeholder 8 punkter: & Visitatorer kan bevillige ydelser. Ydelserne \\
derer borgere og tilkender hiemmehiælp & - personlig pleje & har enten form af pakker fx 'en lille mor- \\
(ex rengøring, hiælp til personlig pleje & - spise og drikke & genpakke', der så vil indeholde et vist antal \\
minutter, eller der findes et ydelseskatalog, \\
osv.). Fælles Sprog indeholder et skema & - mobilitet & hvor alle ydelser er oplistet fx hårvask, \\
til at funktionsvurdere borgeren. & - daglig husførelse & opvask, hiælp til spisning. \\
& - aktivitet & \\
& - socialt samvær og netværk & \\
& - mental og psykisk tilstand & \\
& - sygdom/handicap & \\
& For hvert punkt vurderes borgerens funktionsniveau på en skala & \\
& fra 1-4, hvor 1 er selvhjulpen og 4 angiver massivt støttebehov. & \\
\hline
\end{tabular}

(Danmarks Statistik 2009). I takt med et øget behov for hjemmehjælp steg kommunens udgifter til området. Fra 1990'erne og frem blev der arbejdet på at formalisere aftalen mellem kommune og ydelsesmodtager, og visitationsprocessen og krav om skriftlighed kom i søgelyset. Derudover har der været voksende opmærksomhed på individualiserede ydelser og den $æ l d$ res rettigheder (Balle Hansen og Vedung 2005).

I starten af 1990'erne var KL begyndt at afsøge mulighederne for at skabe et system, der kunne ensarte kommunikationen og fungere som styringsredskab. I 1996 udgav KL rapporten “Ældreområdet. Forslag til fælles sprog vedr. behov og ydelser" og på et seminar i $1997 \mathrm{blev}$ det vedtaget at starte et projekt. Resultatet var kataloget Fælles Sprog, som var parat til brug i 1998 (Balle Hansen \& Vedung 2005: 279). I dag anvender over $80 \%$ af de danske kommuner Fælles Sprog.

De politiske udmeldinger omkring udviklingen af Fælles Sprog har fokuseret på den ældre, der skulle have fleksibilitet i ydelsen, den øgede efterspørgsel og udgiftspres, samt behovet for styring. Opmærksomheden på xldreområdet har i forhold til visitationen i højere grad været rettet mod at styre udgifterne, dvs. at sige nej til ældre og pårørende, og sikre ensartethed i tildeling af services. Finansieringen af hjemmehjælp er kommunal og der er ingen statslige refusionsordninger. Det statslige bloktilskud afhænger dog blandt andet af andelen af ældre borgere i kommunen (Juul 2006).

Evalueringer af Fælles Sprog I (en tidligere version af systemet) peger på, at Fælles Sprog I, ifølge adspurgte visitatorer, gruppeledere og socialdirektører, har medført en "vasentlig standardisering af visitationsprocessen og afgorelsen, og dette er et vasentligt fremskridt, i forhold til hvordan det foregik for Falles sprog. Der er i hojere grad en sammenhang mellem det behov, brugerne har, og de ydelser, brugerne fär" (Balle Hansen og Vedung 2005: 283). Samme evaluering finder dog også, at Fælles Sprog I ikke var velegnet til gruppen af komplekse ældre (Balle Hansen og Vedung 2005: 283).

\section{Analytisk tilgang}

Studier af digitale sagsbehandlingssystemer på hhv. børn og unge- og beskæftigelsesområdet peger på, at der dels sker en påvirkning af sagsbehandlere indirekte ved at de digitale systemer disponerer over sagsbehandlerens tid (Gillingham 2009), mens et andet studie også peger på at dokumentation i systemerne er uensartet og at stort arbejdspres vil mindske omfanget af dokumentation (Dearman 2005, 30:47-65). Disse fund angiver, at digitale systemer kan bruges - og bliver brugt - på forskellig måde. Derfor er praksisvinklen på teknologi vigtig.

Artiklen tager afsæt $\mathrm{i}$ en tradition, der forsøger at overskride dualiteten mellem teknologi og socialitet, der med en samlet betegnelse kaldes Science Technology Studies (STS). Det primære udgangspunkt for STS-tilgangen er fokus på et praktisk empirisk niveau, og man kan derfor sige, at STS i lige så høj grad er en måde at bedrive forskning på - en metode - som det er en teori. STStilgangen er interessant i forbindelse med offentlige organisationer, fordi STS har "medvirket til at udvikle et blik på organisatorisk praksis, som inddrager materialitet ( $\mathrm{fx}$ it, dokumenter og fysiske omgivelser) som en altid tilstedeværende komponent" (Lauritsen et al. 2007: 10). STStilgangen sættes af disse forskere derfor op som alternativ til 'rationalistiske og management orienterede perspektiver', hvor fokus med en STS-tilgang er på den praksis, der foregår i offentlige organisationer. STS-tilgangen kan altså bruges til "empirisk og teoretisk at analysere kløften mellem politiske visioner på den ene side og praktiske processer på den anden" (Lauritsen et al. 2007: 10). Teknologi kan med STS perspektivet ikke betragtes som en fast størrelse, der indføres og dernæst påvirker organisationen. Der ligger heller ikke en forudantagelse om, hvilken rolle teknologi har. Med et STS-udgangspunkt er det netop et empirisk spørgsmål, der skal afgøres ved undersøgelse af konkrete relationer mellem teknologier og organisationer. I det her tilfælde er det visitatorers praktiske processer omkring det standardiserede sagsbehandlingssystem Falles Sprog, der analyseres. 


\section{Digitalisering og professionelt råderum}

Dette afsnit handler om hvordan visitatorers arbejde udfolder sig i et standardiseret system som Fælles Sprog. Først beskrives, hvordan visitatorerne arbejder med de standardiserede kategorier til angivelse af behov og ydelser, og efterfølgende analyseres, hvordan visitatorerne ved at fortolke Fælles Sprog tager individuelle hensyn til den ældre.

\section{Kategorisering af behov og ydelser}

Som nævnt tidligere er tildeling af ydelser til borgere i stadig højere grad bygget på en standardiseret vurdering af borgerens behov. Det gælder også Fælles Sprog, hvor funktionsvurderingen er den standardiserede metode i sagsbehandlingssystemet. En visitator fortæller.

Visitator: "Jeg synes Fælles Sprog er et fint nok redskab til at sikre sig, at man kommer hele vejen rundt. Jeg plejer at sige når jeg kommer hjem til en borger: "... et grundlag for at tildele hjælp, det er min funktionsvurdering af dig", og så gennemgår jeg de her punkter: personlig pleje, mobilitet, mad og drikke osv.. Og jeg synes, ja, det er jo et skema, men det sikrer jo, at man lige husker de allerfleste relevante områder i de allerfleste menneskers liv. I hvert fald med det vi kan kompensere for."

At have en standardiseret metode opleves altså her som en støtte, der hjælper med at huske de relevante områder. Det er interessant at lægge mærke til den sidste sætning i citatet "I hvert fald med det vi kan kompensere for". Det indikerer at visitatorens undersøgelse af den ældres behov bliver styret af, hvilke tilbud kommunen har. Som eksempel på, hvilke behov der ikke afdækkes nærmere, da kommunen ikke har tilbud til det, nævnes ensomhed.

For den enkelte visitator kan de standardiserede kategorier for borgerens funktionsniveau bidrage til at give et hurtigt overblik.

Visitator 2: "Jeg synes, at Fælles Sprog er et godt redskab. Rigtig godt."

\section{Interviewer: "Et godt redskab til hvad?"}

Visitator 1: "Til at få et hurtigt billede af, hvordan den her borger er. Der kan man jo se, hvad det er for en borger, nå men det er en, der kun har hjælp til personlig pleje, eller kun scorer 2 der eller 2 der, det må være en lettere borger. Man får et hurtigt overblik over, hvad for en kategori borger man har med at gøre, og hvilken hjælp de får. For hvis scoren er lav de fleste steder, så er det jo ikke meget hjælp borgeren får."

Det tal, der angives som funktionsniveau, betyder altså noget for servicetildelingen. På ydelsessiden ses samme tendens til standardisering. Det kan $\mathrm{fx}$ være i form af pakker til hjemmehjælp fx morgenpleje. Når behov (i form af den ældres funktionsniveau) og ydelser (i form af servicepakker eller ydelseskataloger) er standardiseret og kan udtrykkes med en kategori bliver det nemmere - både for visitator og ledelse - at sammenholde vurderingen af behov med den tildelte ydelse. Denne standardisering af metoder og brug af standardiserede kategorier til angivelse af behov og ydelser er et af de redskaber, der bruges for at opnå bedre systematik og give mulighed for udtræk af ledelsesinformation. Når kategorisystemer er digitale og kan koble informationer om borgerens funktionsniveau og den ydelse borgeren får, er det dels muligt at aggregere oversigter over kommunens borgeres behov og kommunens udgifter til disse, men derudover muliggør det også et bud på - i kroner og ører - hvor stor en besparelse en sænkelse af serviceniveauet vil medføre. Hvad kan kommunen spare ved fx ved at sænke en servicepakkes minuttal? Det forklarer en visitator der anvender Fælles Sprog.

Interviewer: "Har du indtryk af hvor meget, det bliver brugt som et ledelsesværktøj? Trækker din leder fx information ud af Fælles Sprog?"

Visitator: "Meget. Det er simpelthen et kontrolværktøj. De trækker hele tiden statistikker ud. De trækker lister ud, sådan så man ser; hvor mange får rengøring i distrikt 1? Og lad os nu sige, at det gør 50 borgere normalt, men hov, nu er der pludselig 100 borgere, der får rengøring dér. Der er noget, I må tage fat på, at få nogle af dem fjernet, kunne de finde på at sige. Det er sådan, det bliver brugt, og forleden dag fik vi at vide, at nu har vi brugt 300 timer mere om ugen, end vi gjorde for tre måneder siden. "Hvad er årsagen til det?" Spørger de så. Jeg vil ikke sige, at jeg står skoleret, men jeg skal kunne sige; hvad er det, der har gjort dét? Og det er selvfølgelig, fordi der er kommet nogle dårlige borgere hiem fra sygehuset, som har haft brug for flere timer. Og det er et styringsredskab på den måde, at de kan gå ind og sige: "Pakkerne skal ikke længere være 45 og 60 min, nu skal de være 30 og 45 min". Så bliver der sparet på den måde. Eller man kan sige: "Der er ikke længere noget, der hedder 40 
min, nu kan det hedde max 30 min", og så må man putte oveni, hvis der er et eller andet. Så jo mere firkantede rammer, jo nemmere er det for politikerne at justere op og ned på serviceniveauet."

De standardiserede kategorier til vurdering af borgere og ydelser giver altså forskellige aktører i den kommunale forvaltning mulighed for via det digitale system at få overblik over hvilke services der er tildelt.

\section{Individuelle vurderinger $i$ et standardiseret system}

Den enkelte borgers situation passer ikke nødvendigvis til standardskabelonen for en sag. Så selvom visitatoren har funktionsskemaet fra Fælles Sprog med 8 punkter der skal undersøges, så skal metoden oversættes, når borgerens konkrete situation skal vurderes. I nedenstående beskriver visitatoren en situation, hvor hun mener en sundhedsfaglig baggrund er forudsætning for at forstå og tolke borgerens situation. Visitatoren, der fortæller her, er uddannet sygeplejerske.

Visitator 1: "Når vi fx sidder hos Fru Hansen, og der så ligger en pakke hygiejnebind, så skal vi jo tænke: Hvorfor har Fru Hansen på 80 år hygiejnebind? Jamen, det er måske fordi, hun har nogle problemer med sin vandladning. De ting man ser skal man jo være opmærksom på: "Hov, hvad er det lige for noget?" Så der er jo rigtig mange ting, vi kobler: Hvorfor lugter her sådan lidt, når vi kommer ind? Er det fordi, hun har en kronisk blærebetændelse altid, og så ligger de her hygiejnebind her også...? Ting som andre måske ikke lige ville tænke over. Så vi har jo rigtig meget af vores uddannelse med os hele tiden, og derfor er det også så vigtigt at vi har den her sundhedsfaglige uddannelse, fordi vi jo ser bredt på den måde".

Den anden visitator i samme interview beskriver i nedenstående, at hun er glad for Fælles Sprog og glad for at der er mulighed for at knytte tekst til kategoriseringen. Hendes begrundelse er, at de standardiserede kategorier ikke rummer så meget information og hvis man kun brugte angivelsen af funktionsniveau uden at knytte kommentarer til, ville det kunne give et falsk indtryk af, at der var foretaget en grundig undersøgelse, selvom det måske ikke var tilfældet.

Visitator 2: “Jeg synes, at Fælles Sprog virkelig har nogle gode ting i sig [...] går man stringent efter funktionsvurderingen, så synes jeg måske nok, at det bliver lidt firkantet. Så jeg er personligt meget glad for, at vi har mulighed for at skrive prosatekst. Sådan vil jeg sige det. Og hvis jeg kun skulle bruge tallene, så tror jeg, at jeg ville kunne gemme noget af min faglige inkompetence, havde jeg nær sagt."

Interviewer: "Fordi der ikke er nok information i et tal? Eller hvad tænker du på?"

Visitator 2: "Ja. Jeg ville nemmere kunne dække over, at have glemt noget, synes jeg, end når jeg skal ind og beskrive med ord. Fx den der med inkontinensen [reference til historien ovenfor] og sådan nogle ting, ikke. Der vil jeg nemmere kunne tænke: "Tja ... det fik jeg ikke lige spurgt om, men borgeren sagde jo heller ikke noget". Og så bare sætte et kryds ud for et tal."

Selvom der tages udgangspunkt i en standardiseret metode bygger vurdering af borgeren på en skønsmæssig vurdering. Nedenfor et eksempel fra en visitator, der beskriver hvordan registreringer af borgerens funktionsniveau bygger på en fortolkning - dels af borgerens situation, men også af skemaets kategorier.

Visitator: "Vi har den skala fra 1 til 4 at vurdere borgeren med, og der står jo forklaret ud for niveau 1, hvad man kan [for at blive kategoriseret som etter], og ud for 2 hvad man kan, og ud for 3 hvad man kan, og ud for 4 står der, at man stort set ingenting kan. Og det er de ord, man vurderer efter; er det dér hun skal placeres? Eller dér eller dér? Vi anvender egentlig funktionsvurderingen ens - og dog. Vi har prøvet at have nogle færdige funktionsvurderinger med på fællesmøder, og hvor vi så eksempelvis omkring mobilitet og færden faktisk har vurderet meget forskelligt, fordi; hvad er det at kunne færdes frit? Der står faktisk i Fælles Sprog; "færdes frit med eller uden hjælpemidler". Og nogen har så vurderet, at fordi de går med rollator, så er de en 3'er, og nogle af os har vurderet, at de er en 1'er fordi der står i Fælles Sprog, at de 'færdes frit og ubesværet med eller uden hjælpemidler', ikke, så vi fortolker det lidt forskelligt ..."

Fagligheden spiller også en rolle, når der skal findes individualiserede løsninger indenfor standarden. Hvis 
visitatorerne oplever et behov på grund af en nedsat funktionsevne, men ikke har en ydelse, der passer til, er der mulighed for lidt fleksibilitet i forhold til tildeling af ydelser, men der er klare grænser for fantasien. Serviceniveauet kan ikke fraviges. Som en visitator siger: "det er ret enkelt. Her i kommunen lufter vi fx ikke hund". Men at finde en individuelt tilpasset løsning er muligt indenfor de standardiserede ydelser, som en visitator her fortæller om.

Interviewer: "Oplever I ikke, at I nogen gange sidder og mangler en ydelse?"

Visitator 1: "Nej, vi finder altid et sted at putte den ind - mere eller mindre logisk, hvor man gør det - fx hvis vi bliver bedt om noget, vi ikke umiddelbart har, så tager vi den op på morgenmødet, og så finder vi altid en løsning kollektivt. Så vi giver ikke bare noget, før vi har drøftet det, hvis ikke det lige er oplagt i vores ydelseskatalog [dvs. ydelser, der kan bevilges]. Nu var der fx her til morgen en blind borger, der havde brug for hjælp til at få gjort rent på sit toilet hver dag - og i sit køkken og som havde ydelsen "Hjælp til morgenmad", men hun laver selv morgenmad. Og udførerne bad om at få et antal minutter til at gøre det her, og så har vi den lige oppe, for normalt kan vi jo kun give rengøring hver 14 . dag, så hvad skulle vi gøre her? Så sagde vi, at morgenmad, der er jo også opvask i den ydelse, men det har jo ikke noget at gøre med, at gulvene er fedtede. Så må vi finde ud af, at vi bruger rengøringsydelsen hver dag, fordi det er en særlig situation. Så på den måde er man ikke hæmmet, men man er nødt til at gå lidt uden for standarden, fordi det skal jo være lidt individuelt. Men vi opfinder ikke bare en anden ydelse, vi bruger nogle af dem, der er, og så må vi bare skrive og begrunde det godt."

Ovenstående er et eksempel på visitatorer, der med udgangspunkt i deres individuelle vurdering af en borgers behov får aftalt en løsning på tværs af de standardiserede ydelser. Både dette eksempel og det ovenfor igen illustrerer, at det er i visitatorernes oversættelse af det standardiserede system, at de individuelle hensyn bliver mulige at tage.

Fælles Sprog gør det ifølge visitatorerne nemmere at få et hurtigt overblik og kategoriseringerne kan systematisere vurdering af borgeren og tydeliggøre, hvilke forhold der er indgået i vurderingen. Fælles Sprog giver mulighed for at lave dataudtræk, der fungerer som alarmklokker for ledelsen i tilfælde med overskridelse af budgettet. Når det kommer til individuelle hensyn og hensyn til borgeren, er det imidlertid visitatorens fortolkning af Fælles Sprog, der er afgørende. Det kan være i fortolkning af funktionsskemaets kategorier eller ved at tildele en ydelse, men aftale med udførerne, at den skal leveres på en anden måde. Visitatorerne bruger altså deres faglige baggrund og skønsmæssige råderum til at håndtere de modsatrettede hensyn mellem standardisering og individuelle vurderinger.

\section{Et kig i krystalkuglen}

I ovenstående er der redegjort for, at det individuelle hensyn er afhængigt af, at visitatorer vil og kan bruge deres skønsmæssige råderum til at fortolke og udfordre det standardiserede system Fælles Sprog. Følgende vendes blikket fremad, og sagsbehandlingssystemets konsekvenser for skønsudøvelse diskuteres. Vil balancegangen, der sikrer såvel standardisering som fagligt råderum, kunne fastholdes på langt sigt? Nedenstående eksempler indikerer, at det er værd at være opmærksom på, hvordan balancen kan opretholdes. En visitator giver udtryk for, hvad hun opfatter som sin opgave.
Visitator 1: "Nøjagtig ligesom færdselsbetjen- ten ikke skal vurdere, om man må køre 110 eller 130 km i timen på motorvejen, så skal vi heller ikke vurdere, i virkeligheden, om det er rimeligt. Vi kan sagtens have vores personlige meninger [...]. Men vi skal ikke vurdere, om det er synd for borgeren, at borgeren kun kan få gjort rent hver anden uge, hvis det er det, der står i vores "færdselslov", altså vores kvalitetsstandard. Så er det jo dét, vi skal gå ud og udmønte."

Citatet kan fortolkes som om, at visitatoren ovenfor oplever et mindsket skønsmæssigt råderum og derved føler mindre ansvar for de afgørelser hun træffer. Derved stilles der også spørgsmålstegn ved, om det at visitere til ydelser er en faglig opgave, der kræver skønsmæssigt råderum, eller om der er tale om at følge en "færdselslov". Hvis det ikke længere opleves som en faglig opgave at vurdere borgerens behov eller finde den rigtige løsning på et problem, kan man frygte, at det på længere sigt vil medføre problemer i forhold til at rekruttere fagligt dygtige medarbejdere.

En anden visitator fortæller noget lignende, bare med udgangspunkt i kontakten med borgeren, hvor kommunens kvalitetsstandard bruges som en slags beskyttelse overfor borgeren og til at legitimere afgørelser. 
Visitator 2: "Hvis der sidder nogle pårørende, der godt kan blive lidt sure over, at moderen ikke kan få, hvad hun gerne vil have. Når du så forklarer standarden i kommunen, så får du en helt anden dialog. [...] Det giver en større forståelse hos de pårørende. Det er nok det med, at det jo er politisk besluttet, de her standarder. Man oplever nogle gange, at når man kommer ud og borgeren ikke er berettiget til hjælp og jeg giver afslag, så siger borgeren: "Nå, har du en dårlig dag i dag? Skal du have mere i lønningsposen?" Så må jeg sige til dem, at sådan er det altså ikke. Og så er det godt at have standarden og kunne sige, at de er nødt til at indordne sig under de her regler, og reglerne gæelder alle."

Visitatoren oplever, at borgerne stiller spørgsmålstegn ved legitimiteten af hendes afgørelser. Hun vælger at argumentere med standarden - at alle skal indordne sig under samme regler - fremfor sundhedsfaglige argumenter for, hvorfor afgørelsen er faldet sådan ud. Opleves afgørelser med bund i standarder som mere legitime af både borgere og visitatorer, kan man forestille sig, at fravigelser fra standarden bliver mere sjældne endda i tilfælde, hvor en individuel vurdering ville tilsige det. Borgere er forskellige, lever forskellige liv og kan have forskellige behov. I takt med at sagsbehandlingssystemer integrerer standardiserede løsninger, kan man forestille sig, at de kreative løsninger, hvor sagsbehandleren med udgangspunkt i en borgers specielle situation strikker en individuelt tilpasset løsning sammen, bliver færre. Det vil mindske træfsikkerheden, altså at borgeren får den rigtige ydelse.

Det nyeste sagsbehandlingssystem i rækken, DHUV (Digitalisering Handicap og Udsatte Voksne) bygger på nogle af de samme principper som Fælles Sprog og udbredelsen af digitale sagsbehandlingssystemer vil højest sandsynligt fremme brugen af kategorier og standardbegreber, da det er nødvendigt dels for at kunne lave udtræk af ledelsesinformation og dels for at forskellige systemer kan udveksle data. Denne artikel har taget udgangspunkt i ældreområdet, der ikke er et specielt kompliceret område. At have mulighed for at tilpasse standarden må være så meget desto mere nødvendigt i relation til borgere med komplekse sociale, fysiske eller psykiske problemer. Eller når ydelsen er meget personafhængig som ved ydelser til borgere med psykiske lidelser, hvor kvaliteten blandt andet også afhænger af at kemien mellem borger og ansat er god.
I Stanley Kubricks film Rumrejsen 2001 bliver computeren HAL spurgt, om han ikke er nervøs over det store ansvar, der påhviler ham på rumrejsen. HAL svarer: "The 9000 series is the most reliable computer ever made. No 9000 computer has ever made a mistake or distorted information. We are all, by any practical definition of the words, foolproof and incapable of error".

Denne tro på, at det perfekte digitale system eksisterer, er der nok ikke mange, der deler med HAL. En forudsætning for at der kan tages individuelle hensyn i indsatsen er derfor sagsbehandlernes faglige omgang med de standardiserede systemer og deres improvisation over dem. Har sagsbehandlerne ikke viljen og kompetencerne til at gøre det, risikerer systemet at komme i centrum frem for borgeren. Derved kan det blive et mål i sig selv at anvende systemerne rigtigt. Så ender det med kun at være en digital vej, og ikke en digital vej til velfærd.

\section{Referencer}

Bjørnholdt, K 2011, Det har ikke varet godt nok. København: Dansk Politi.

Bovens, M \& S Zouridis 2002, "From Street-Level to System-Level Bureaucracies: How Information and Communication Technology Is Transforming Administrative Discretion and Constitutional Control." Public Administration Review 62(2): 174-184.

Danmarks Statistik 2009, Nyt fra Danmarks Statistik, Danmarks Statistik. 292

Gillingham, P 2009, The Use of Assessment Tools in Child Protection: An Ethnomethodological Study. Melbourne: University of Melbourne.

Hansen, MB \& E Vedung 2005, Falles sprog i aldreplejens organisering. Evaluering af et standardiseret kategorisystem. Odense: Syddansk Universitetsforlag.

Hood, C, C Scott, et al. 1999, Regulation inside Government. WasteWatchers, Quality Police, and Sleaze-Busters. Oxford: Oxford University Press.

Høybye-Mortensen, M 2011, Velferdsstatens dorvogtere: Procesregulering af visitationer på socialområdet. Ph.d.-afhandling. Institut for statskundskab. København: Københavns Universitet.

Juul, T 2006, Håndbog i kommunernes og regionernes nye økonomi. København: Jurist- og økonomforbundets Forlag.

Lauritsen, P, C Bruun Jensen, et al. 2007, Introduktion til STS, København: Hans Reitzels Forlag.

DSL (Det Danske Sprog- og Litteraturselskab) 2012, Den danske ordbog - Moderne dansk sprog, København: DSL - Det Danske Sprog- og Litteraturselskab.

Lundquist, L 1992, Förvaltning, stat och sambälle. Lund, Sweden, Studenterlitteratur.

Marston, G 2006, "Employment services in an age of e-government." Information, Communication \& Society 9(1): 83-103.

Regeringen 2012, Danmark i arbejde: Udfordringer for dansk økonomi mod 2020. Statsministeriet.

Regeringen, K. L., Danske Regioner 2011, Den digitale vej til fremtidens velfard. Den fællesoffentlige digitaliseringsstrategi 2011-2015.

Vedung, E 2005, Policy instruments: typologies and theories. Carrots, sticks \& sermons. Policy Instruments \& their evaluation. ML Bemelmans-Videc, RC Rist og E Vedung, Transaction Publisher. second: $21-58$. 